\title{
THE CONTINUITY OF ENGLISH EQUITY
}

Two recent articles which attempt to point out the bearing of various facts of detail, recently stated by different investigators, upon the continuous history of English equity leave something still to be desired. These articles are, in the order of date, my own, entitled The Origin of English Equity, ${ }^{1}$ and Dr. W. S. Holdsworth's, entitled The Relation of the Equity Administered by the Common-Law Judges to the Equity Administered by the Chancellor. ${ }^{2}$

In my article the attempt was made to show that the facts earlier and more recently brought to light prove that both the later systems, equity and common law, had their origin in the twelfth century in the same set of facts; that they were then identical, undistinguished and indistinguishable; and that the differentiation between the two systems took place in the course of the thirteenth century by the hardening of common-law forms and the separation of the common-law courts from the common line of growth, while the more free and unrestricted development which gave rise to equity was continued by the Council. Of their relation to one another in the twelfth century, I said, having regard to the character of the principles in which both originated, that "if we wish to assign to either a precedence in time we must say not that equity originated in common law but that common law originated in equity."3 And of the final development of equity, I said "that as the organ of the king's prerogative, the Council was the natural organ for the exercise of his equitable powers in interference in the field of common law and it is therefore under the Council that the modern system of equity developed." 4

Dr. Holdsworth approaches the subject from a different point of view. The problem he discusses is: Did the equity system of the fifteenth and sixteenth centuries develop out of the equity administered by the common-law courts of the thirteenth and early fourteenth centuries? The cases in the common-law courts

2 (IgI6) I6 CoL. L. Rev. 87-98.

2 (Ig16) 26 YALE LAW Journal, I-23.

3 (Ig16) I6 CoL. L. Rev. 94.

-Ibid., 98. 
of the thirteenth century in which appeal is made to equitable considerations and doctrines are known to be so numerous that "they raise the important question whether the equity which the common-law judges administered in these cases can be regarded as the beginnings of the system of equity developed by the chancellor; or whether these early equitable doctrines so completely died out that we must regard the chancellor's equity as a new and a different development." "His conclusion that we must is stated in these words:

"Whether we look at the court which administered it, at the procedure which that court employed, at the theory upon which equity was based, or at the contents of the equitable rúles, we see a striking contrast between these two phases in the administration of equity. It is so striking that we must conclude that our modern system of equity created by the chancellor is, not a continuation of the equity administered by the common-law courts, but a new, a distinct, and an independent development."

Between the conclusions reached in these two articles, as stated above, there is no necessary disagreement. But the words used by Dr. Holdsworth in stating his conclusion, "we must conclude that our modern system of equity is a new, a distinct and an independent development," inevitably raise the question whether the identical beginnings of common law and equity in the twelfth century are not by these terms also excluded from the origins of equity, and whether it is not intended to imply that all the equitable considerations and practices of the twelfth century are absorbed into the development of the common law leaving no surviving and separate line of growth into the later equity system; whether in a word the new and independent beginning referred to is not the farthest point to which we can trace back our modern equity system. This point should be considered anew and the endeavor made to show if possible in what respects the history of equity is continuous, not into the thirteenth century merely but into the sixteenth. In such a study there is, I think, no question as to the facts. The question is as to the interpretation of the facts.

In a discussion of this kind there is one preliminary consideration which is important. While Dr. Holdsworth does not overlook the development of the institutional side of equity, the

(IgI6) 26 Yare Law Journal, 2.

'Ibid., 23. 
relation of equity for instance to the Council, and especially does not in his History of English Law, the main interest of his article is in the body of doctrines and equitable considerations upon the principles of which the system was administered. ${ }^{8}$ If one is considering the content of equity as distinguished from the common law that is a highly important, indeed the necessary matter to be studied. For a student of the history of law, regarded as a body of ideas and doctrines, of precepts and fundamental principles, the question when and from what source these elements entered into the historical current of the law, and what changes they made in the then existing body of law is the essential thing to be studied. Such a study will include also the way in which these new considerations modified or rendered obsolete existing procedure, or introduced new and supplementary forms. I hardly think it is likely, however, that any student of legal history will maintain that the study of these matters constitutes the whole of the history of law. Legal history regarded as a whole is a history of institutions as well as of doctrines, and it cannot be complete until the influence of each of these two factors in producing the common product is shown in its due proportion. Law can act upon practical affairs only through institutions, and these two sides are indeed so closely connected that it is impossible for any student whose main interest is in one side to give an account of his subject without treating more or less fully of the other. In each of the two articles here considered this overlapping of fields has occurred, though the main interest of each is different from that of the other.

As I have implied above, the main interest of Dr. Holdsworth's article is in the content of equity, the sources of the considerations and doctrines which have developed or changed its content and in some cases its practices as well. Among these new doctrines those which attempt to state the grounds on which equity rests its right to act must unquestionably be regarded as distinctly fundamental, clearly indicating contemporary ideas and decisive in influence on the future. It should be said that Dr. Holds-

\footnotetext{
'See Holdsworth, Hist. Eng. Law, Vol. I, pp. 194-205, 264-285.

${ }^{8}$ See the passage cited at note 5. "Thus the equitable principles which we can discern in the common law right down to the beginning of the fourteenth century gradually evaporated. It was this fact which made the intervention of the chancellor necessary." (I9I6) 26 Y YLE LAW JOURNAI, 22 .
} 
worth has shown that considerations of this character entered the history of equity at a date later than the thirteenth century and profoundly affected the development from that time on, so that we must say that the equity of the Tudor age rested itself in part at least upon grounds which would not have been advanced in the twelfth and thirteenth centuries. It is an important part of the present question whether these fundamental considerations so profoundly affected the nature and character of the existing system into which they came as to mark the beginning of a new and independent development back of which we cannot trace the history of modern equity, even as a system of doctrines. This is however only one portion of the question and our decision as to the continuous history of equity from the twelfth century can only be made when the whole of that which is developing together is taken into the account.

Upon the institutional side I think we are compelled by virtue of facts which are familiar enough to say that there is no break in the continuity of the development. There is no point after the beginning in the twelfth century where there originates a new and independent institutional development. The differentiation of the chancellor's jurisdiction from the Council is not a new beginning. It is merely an ordinary case of differentiation, slowly brought about, with no conscious intention, exactly like the earlier differentiations of Exchequer and King's Bench from the Council. ${ }^{\circ}$ So homogeneous and consistent within itself is the entire process of growth that it is possible to represent it graphically in a rough chart. Although such a representation is mechanical, it should be clearly seen that the process which it depicts was not mechanical. It was a living growth in which at no moment were contemporaries conscious that any radical or

There is of course one difference in the fact that the jurisdiction of the chancellor as an equity judge he himself had never exercised alone in the Council. His jurisdiction as the sole judge of a court never existed anywhere but outside the Council. This is not true of the body of barons and justices who by degrees formed the separate courts of Exchequer and King's Bench. There is in the history of each of these institutions a period where a specialized body of council members, still practically within the Council, performed the functions soon to be differentiated into new institutions. The same thing is true of the court of Star Chamber and of the present House of Lords as a supreme court. But this peculiarity of the differentiation of the chancellor's jurisdiction is not of importance from the present point of view. 
revolutionary change had occurred. Each stage in the development, each differentiation, came about so gradually, by such minute and natural changes, that they were wholly unsuspected. The changes indeed, measured after long lapse of time, are seen to have worked no greater transformation than those wrought in similar periods in the history of the English language, and like these no man in the line seemed to himself to be doing a different thing from his father.

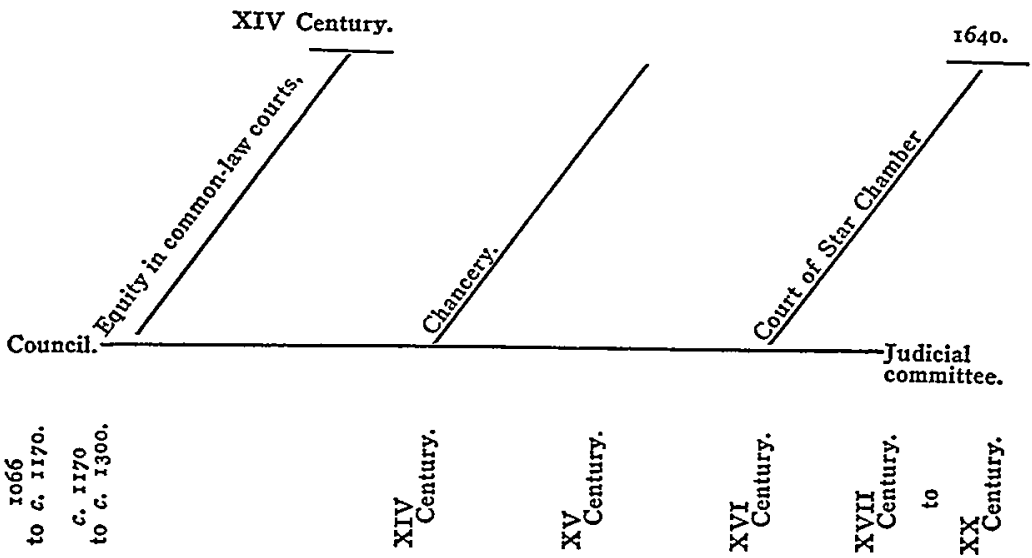

The first period, I066 to $c$. II7o, is the period of equity as prerogative action, not yet distinguished from other prerogative action, and not yet looked at theoretically, administered by the Council, great ${ }^{10}$ and small; that is, by the Curia Regis, or by royal commissioners appointed for special cases, who hold a local Curia Regis. The action of the court is occasional only and by special permission. The second period from $c$. II70 to $c$. I300, is that introduced by the judicial changes of Henry II. New royal courts were created specially to administer the prerogative interference with the ordinary procedure on equitable

\footnotetext{
${ }^{10}$ It will be understood of course that the mention of the great Council means no more than that the same powers were possessed and the same functions could be exercised by the great as by the small Council. As a matter of fact it is almost always the small Council that is acting in the cases that we know, and it is always from it that the differentiations take place. It is true also that neither great nor small Council, exactly considered, made use of the new prerogative procedure of the common-law courts, though it would be difficult to say why not, and though the Council as coram rege seems to have done so in a limited way.
} 
This equitable jurisdiction of the Council rapidly increased in importance during the fourteenth and fifteenth centuries, and somewhere in the fourteenth the chancellor began imperceptibly to relieve the Council of some of this work ${ }^{14}$ and so by degrees to draw off more and more of this equity jurisdiction until what we know as equity proper had been withdrawn from the Council. The chancellor's court had become distinct from the Council before the end of the fifteenth century. ${ }^{15}$ It is along the line of this court that the great body of equitable doctrine and practice came down to us. But if the equity system proper was now dissociated from the history of the Council, that body did not cease to be the organ of the king's prerogative in its superior function of correcting and supplementing the ordinary law, the same function from which equity had originally grown. In exercising that function it continued to be a court. Both these facts are clearly to be seen in the preliminaries which led to the court of Star Chamber and in the history of that body. ${ }^{18}$ The progressive separation of the court of Star Chamber from the Council is more closely parallel to that of the Exchequer and of the King's Bench than to any of the other cases of differentiation, ${ }^{17}$ and the court is for a long time rather the Council itself, or a special body of the councillors acting in a particular capacity, than a distinct court. This is perhaps the reason why the changes of 1640 left hardly any of the old judicial functions remaining in the Council. The abuses of which Parliament

${ }^{16}$ Perhaps the first impulse to this differentiation came from the statutes of 8 and 2I Edward I., in regard to the classification of petitions and their disposition. See Holdsworth, Hist. Eng. Law, Vo1. I, pp. I73, 197.

${ }^{15}$ The chancellor sat alone as a judge as early as the reign of Richard II; Baildon, Select Cases in Chancery (S. S.) xvi; but the chancery was hardly a distinct court until near the end of the fifteenth century, ibid., xix; Holdsworth, Hist. Eng. Law, Vol. I, p. I99.

${ }^{16}$ See Holdsworth, Hist. Eng. Law, Vol. I, pp. 27r-285.

${ }^{17}$ The analogy between Star Chamber, King's Bench and Exchequer at one point in the process of their differentiation and the present position of the House of Lords as a court of law is very close and especially instructive because the differentiation of the House of Lords as a court has been arrested in mid-process. It now appears stationary in the position where the court is composed of a special body of members of the large body acting alone for this particular function, but clearly as being in theory the larger body, and themselves remaining members of the larger body for all purposes. This was exactly the case with the Star Chamber under Henry VII and with the King's Bench in Bracton's time, and the Exchequer a generation earlier. 
grounds. These were the Itinerant Justice courts and the central court of Common Pleas. Prerogative action was still the special function of the Council and, by reason of that fact, the operation of these new courts was under the supervision of the Council, to which important and difficult cases were reserved ${ }^{11}$ and which during the period began a jurisdiction in error. ${ }^{12}$ The action of the Council in this connection came soon to be known as coram rege and was the germ of the future King's Bench court, which can hardly however be said to be differentiated as a distinct court till near the close of this period. The equity procedure which in the preceding period had been occasional and special only, was now opened to all and regularized, but the forms by which it was regularized tended rapidly to become fixed and hardened, so that the free and untrammelled operation which was general earlier was gradually left to the Council only. This process of fixing and hardening was that by which the body of the common law with its courts became distinguished from equity proper which remained the function of the Council. This is the state of things which characterized the next period, the fourteenth century. Equity could still occasionally be administered by the common-law courts, especially by the General Eyre, but this was a survival only and ceased before the close of the century. The true line of the development of modern equity in this age is to be found in the action of the Council, great and small, at the beginning still in function undistinguished from each other, ${ }^{13}$ upon petition and still clearly based upon prerogative.

\footnotetext{
${ }^{11}$ Gesta Regis Henrici Secundi, Vol. I, p. 207.

${ }_{12}$ Patent Rolls, I232-1247, I62; Bracton, f. I08. The justices of the Bench seem sometimes to have corrected the itinerant justices. See Bracton's Note Book, No. 1445.

${ }^{13}$ While equitable action seems to have been primarily the function of the small Council, as indicated for instance by the address of the majority of the petitions, the fact of the absorption of the small Council in the great at the time of a meeting of Parliament is more clearly indicated to us in the records of the time of Edward I than before. This is the meaning of the phrase consilium in parliamento which made its appearance as a common phrase about this time, in which consilium means the small Council. The expression would seem to indicate that the relation between the two Councils, or perhaps the difference between them, is more consciously regarded than it had been earlier. For this reason I have said in the text that it was in function that they were still undistinguished. On the jurisdiction of the Council at this time see Maitland, Memoranda de Parliamento (Rolls Series) 1xxix-lxxxix, especially lxxxv.
} 
complained seemed quite as much those of the Council as of the Star Chamber. Its appellate jurisdiction, however, survived and it is in that particular that it has come down to its modern form, the Judicial Committee of the Privy Council, constituting a court of appeals rather than one of original jurisdiction. The Judicial Committee is however the direct lineal descendant of the Council from which the Star Chamber separated in the sixteenth century, the chancellor's equity court in the fifteenth, and the common-law courts in the thirteenth. As Dr. Holdsworth

says:

"The act of the crown in allowing or dismissing an appeal, according to the advice contained in the report of the Judicial Committee, is the lineal descendant of the judgment given by the king in person in the Curia Regis." 18

There is no escape from the conclusion that institutionally the modern system of equity has come down to us in a continuous and unbroken growth from the system of prerogative action of the first Anglo-Norman kings, which was started upon a new development by the reforms of Henry II. There is no point between I066 and the twentieth century where there occurs such a break that we cannot easily see the passage of the institutions which were administering equity through and beyond it. In fact there is no break at all. The institutional history of equity is as continuous as the history of the English language from the same date.

What we have now to consider is whether, into this line of institutional development, there entered at any point new doctrines and theories so fundamentally changing the character of the body of equity which was accumulating from stage to stage as to constitute, in spite of the institutional continuity, a new, distinct, and independent development, marking thus a date before which modern equity was not beginning to form.

In the first place, it should be noted that any peculiar developments in equitable considerations or procedure appearing in the common-law courts of the thirteenth and early fourteenth centuries can hardly be expected to affect the later development of equity proper. ${ }^{19}$ They lie clearly outside the line of

${ }^{18}$ Holdsworth, Hist. Eng. Law, Vol. I, p. 294

${ }^{10}$ In studying the cases of Bracton's time with reference to their possible later use as precedents, it would be important to distinguish those cases which are really common-law cases from those which are Council, or coram rege cases, if it were possible to do so. In some cases it is possible 
continuous growth. If they do affect later equity, it can only be because they have been borrowed, not because the later doctrines or procedure have come out of them by a natural process of growth. The natural process of growth does not follow that line. The common-law line of equitable practices and doctrines alike is doomed to early and complete extinction. It has no natural descendants. It is a distinct advantage to have it clearly shown, upon the side of doctrines that no such connection exists; that even borrowing did not take place; but, except as to borrowing, the same assertion could be made, a somewhat a priori assertion perhaps, from a study of the line of institutional descent. ${ }^{20}$

In the second place, it should be noted that the original justification of the right of equitable interference, the supreme duty of the king to secure justice to all, as carried out by the royal prerogative, continued as the chief justification of equitable

but not in all. The headings of the rolls cannot be taken as final evidence. I think there can be no doubt but that a councilman of Edward I's time would have regarded a true coram rege case of Bracton's period as distinctiy in the line of council precedents. And there was as yet very little reason why it should not be so considered. Bracton could hardly have thought of King's Bench and Council as two courts staffed by the same men. They were to him only one court acting sometimes in one way and sometimes in another, sometimes with a larger and sometimes with a smaller and more special staff. The reason why such common-law features as enter into coram rege cases in Bracton's time (and they are much fewer than would appear in a careless reading of the records) do not affect later Council development, is not because coram rege is then something different from the Council, but because the distinction between common-law action and Council action is becoming from Bracton's time on and in the whole situation rapidly sharper and clearer. As the commonlaw system becomes more and more a fixed system, the more free and unrestricted possibilities of action by the Council as the organ of prerogative, stand out more clearly.

${ }^{20}$ If $A$ represents a continuous line of development from which $B$ at some early point branched off, we should expect B to continue to show for some time characteristics which belonged to the original-line before the separation. But we should not expect $A$ to owe anything to $B$, either to B's independent development of the characteristics which had belonged to the undivided line, or to the distinct developments which it had brought in as original additions since the separation. Direct borrowing from one line might indeed affect the other, but there could be no cross influence of the forces of natural growth. These have been split and separated into two channels by the differentiation. This reasoning applies as well to tribunals and procedure as to doctrines. 
interference by the Council proper so long as that interference continued. ${ }^{21}$ Such action by the Council undoubtedly survived two great crises in its history, one at the point where the common-law courts were differentiated ${ }_{i}^{22}$ and one where the chancellor's court was differentiated. It apparently succumbed in the next crisis of its history when the court of Star Chamber was destroyed. But so long as it survived its justification was always found in the royal prerogative, in the supreme function of the king in the state.

The essential fact characterizing the whole development is not the petition to the king which opens the proceedings, that is merely a method of setting the machinery at work, though a significant one; nor is it the fact that the remedies provided are an interference with the ordinary system of justice, that is a characteristic of the result though it would seem to be an inseparable characteristic, expressed or latent. The essential fact is the existence of the king's prerogative; that is, of a power recognized as above the ordinary every day machinery of the state, whatever that may be at any given time, and free therefore from the rules and regulations which condition the running of that machinery. For this reason it is at liberty to act as above the law to secure any sufficiently important object, the furnishing of justice to all, the enforcement of the rule of conscience, the establishment of a system of criminal equity, the suspension of a statute for a special purpose, the creation of a new offense by proclamation, or the pardoning of a convicted criminal.

If there was introduced into the history of equity a new doctrine explanatory of its right to act so fundamental as to constitute a new beginning, back of which we cannot trace the history of modern equity, the introduction must have taken place

${ }^{21}$ Holdsworth, Hist. Eng. Law, Vol. I, p. $28 \mathrm{I}$.

${ }_{22}$ I hardly think it will be thought by anyone that the differentiation of the common-law courts with their equitable powers brought to an end the equitable jurisdiction of the central curia regis, that is of the great or small Council, so that it would have to be revived again after the new common-law courts had proved, from the hardening of their procedure, inadequate. There is too large a mass of evidence of the continuance of this Council jurisdiction throughout the thirteenth century to permit such a supposition. Interesting cases are: Bracton's Note Book, Nos. 857, I106, II33, I221, I235; Patent Rolls, 1225-1232, I3I; Red Book of the Exchequer, то13; see (I916) I6 CoL. L. Rev. 87, n. I. The number of cases illustrating the general as well as the equitable jurisdiction of the Council in the thirteenth century is large. 
at some point after the line of the development of equity proper had parted from the line of the development of the Council's jurisdiction. In the latter line the original explanation continues unchanged to the end.

That is what occurred, I take it, as indicated by the facts presented in Dr. Holdsworth's article. It is directly in the line of the development of the equity system proper, which in the end passes under the jurisdiction of the chancellor, that the new doctrine entered and the new results occurred. The new doctrine is that it falls within the function of the equity court to enforce the rules of reason and of conscience. This new doctrine assured a broader function than that of securing justice to all. It enabled the equity court to insist that faith should be kept in cases where the common-law courts could not act from lack of some condition which they regarded as essential, as of a formal agreement, or of some other necessary evidence. It enabled it to insist that unjust advantage should not be taken of ignorance or folly; that fraud should not succeed because mere forms were on its side, or because the common law had not provided an exact remedy. ${ }^{23}$ To most if not all of these cases the older principle that justice must be secured, if stated barely and alone, did not seem to be of immediate application. It might at least be plausibly said by the counsel for the defendant that the prerogative of justice had no ground on which to interfere. If the feoffee to uses converted to his own use the property which had been conveyed to him to the use of another, justice as that was interpreted at least by the rules of the common law was satisfied. The forms under which the conveyance had been made legally permitted such action by the feoffee to uses. If the confiding cestui que use supposed his interests would be safe, he had himself to thank for his loss.

${ }^{23}$ The attitude of counsel towards the new doctrine and how the commonlaw court would act are significantly shown in a case cited by Maitland from a manuscript Year Book of Edward II. I Year Books of Edward II (S. S.) xix: "Once in the name of good faith he [Bereford, C. J.] urged the defendant's counsel to admit a fact that had not been proved. Back came the retort: 'You must not allow conscience to prevent your doing law." "References to conscience as a guide of action begin early in the history of the law. Bracton says, speaking of the jury: Si autem nec adhuc sciri possit veritas, tunc discere oportebit de credulitate et de conscientia ad minus. Et in quo casu non committunt perjuriam, quia contra conscientiam non vadunt, ut infra plenius dicetur de convictionibus.
Bracton, f. 186 . 
This was at least a plausible argument and, if nothing of more direct application than a bare appeal to justice could be adduced as ground of interference, the equity judge might well hesitate. Here entered the rule of conscience, that faith ought to be kept, and the equity judge found it no long step, a simple and obvious step indeed, to say that the function of his court already established and widely developed to secure justice, rightly enabled him to enforce good faith and to prevent injustice through a fraudulent use of legal forms. Conscience was not asserted as a substitute for the prerogative of justice, that is as an independent basis of interference, but as proof that in a peculiar set of cases prerogative had the right to interfere. It was urged to show that in these cases prerogative had the right to interfere in order that what was really justice might be secured. ${ }^{24}$

In this explanation I am carrying only slightly, if indeed any farther, a suggestion derived from a paper read by Professor Vinogradoff before the Berlin Historical Congress in 1908 and printed in the LAw Quarterly Review. ${ }^{25}$ In that paper Professor Vinogradoff is primarily concerned to show the source from which the doctrine of conscience was derived and through what intermediaries it made its way into the system of English equity. In developing this subject he distinguishes at one point between those portions of equity in which the new doctrine found application and those in which it was not needed. He says:

"The lawyers and ecclesiastics employed in framing equity jurisprudence in the light of conscience were primarily concerned with the application of three doctrines: equitable remedies had to be provided for those who had not understood how to avail themselves of their legal

${ }^{25}$ What was to be secured may indeed not improperly be directly called justice. Says Professor Ames:

"In most of these cases [after enumeration of certain classes of cases] it will be seen, the plaintiff is seeking restitution from the defendant, who is trying to enrich himself unconscionably at the expense of the plaintiff. Certainly in these instances of early English Equity, Chancery was giving effect to an enlightened sense of justice." (I908) 2I HARV. L. REV. 262.

"The spectacle of feoffees retaining for themselves land which they had received upon the faith of their dealing with it for the benefit of others was too repugnant to the sense of justice of the community to be endured." Ibid., 265. This article on the origin of Uses and Trusts is reprinted in Select Essays in Anglo-American Legal History, Vol. II.

${ }^{25}$ (1908) 24 LAW QUART. Rev. 373-384. 
rights; transactions based on confidence should be protected; promises of parties to contracts should be enforced in certain cases, even if the ordinary legal formalities had not been complied with. There are other points about the equity jurisdiction of the chancery, for example the greater laxity as to certainty of claims, the putting down of maintenance, discovery in procedure, etc., but they proceeded from other points of view than that of conscience and it is to the latter only that we have to attend."

That is to say there was at the time of the introduction of the new doctrine a considerable portion of equitable jurisprudence, developed during its past history in which no application of the new doctrine was made, because it was not needed, and this continued to be an essential portion of equity jurisprudence. It is into this indeed that the new results, however wide their reach, were incorporated. They formed no new and independent body of jurisprudence distinct from the rest of equity.

A special case cited by Professor Vinogradoff shows how the new principle was introduced in the portion of equity to which it was applied.

"In a case tried in Chancery in I467 (Y. B. P. 8 Edw. IV. f. 4, IIpl.) Genney, counsel for the defendant, tried to argue that the plaintiff had not taken care to follow prescribed rules as to covenants, and, if he suffered thereby, it was his own folly. The Chancellor, Bishop Stillington, granted a subpoena and justified his action in the matter by a characteristic maxim: Deus est procurator fatuorum. . . God acts as attorney to foolish people. The maxim bears the stamp of rough and ready mediaeval clericalism, and it opened the way for the Chancery to look behind the external regularity of all corts of transactions with a view to the redress of wrongs committed by skillful miscreants who had taken advantage of weakness of intellect, insufficient knowledge, or casual

This is a special case but undoubtedly it did not stand alone and it shows clearly how the rulings of the chancellor would introduce the new doctrine into the body of equity.

The change in equity which resulted from the introduction of the rule of conscience has been I think in outline correctly described in the above sketch. The change was made in a line of development already going on, and continuing to go on, not as a revolutionary or destructive change, cutting off the past, 
but as adding new life and power of growth in harmony with the past. Such a result is also what we should normally expect from the institutional continuity of the equity system. The growing complexity of the business life of the community, especially the wide extension of the practice of uses, created new legal needs which equity supplied by corresponding extensions of its fundamental principles, extensions always in harmony with the old, though made by the help of doctrines borrowed from without and leading into new and larger fields of action. There is no break in continuity. Keeping in mind the difference between common law and equity, the change, both in process and in result, is analogous to that which was made in the common law by the introduction and extension of the writs of entry and of trespass. ${ }^{26}$ Even if the new doctrine had come to be in the course of time the sole basis of modern equity by the disappearance of the classes of cases to which there had been originally no need to apply it, nothing more than this could be said historically. Large new fields were opened but they were added to the old, not put in the place of them, and both old and new have continued to be diligently cultivated together to the present day.

Grorge Burton Adams.

YALE UNIVERSTTY.

\footnotetext{
${ }^{20}$ That is, keeping in mind the fact that in such expansion what the common law needs is not new justification of action but new forms, and what equity needs is not new forms of action but new justification.
} 